\title{
Oncogenic Signal and Tumor Microenvironment in Hepatocellular Carcinoma
}

\author{
Naoshi Nishida Masatoshi Kudo \\ Department of Gastroenterology and Hepatology, Kindai University Faculty of Medicine, Osaka-Sayama, Japan
}

\section{Keywords}

Hepatocellular carcinoma $\cdot$ Oncogene $\cdot$ Molecular targeting agent $\cdot$ Microenvironment $\cdot$ Immune checkpoint inhibitors

\section{Abstract}

During tumor development, several immunosuppressive molecules are released from cancer cells and contribute to the establishment of immunosuppressive tumor environment. In tumor tissues, cytokines, chemokines, growth factors, and metabolites are present and could counter the effects of immune checkpoint inhibitors. From this point of view, monotherapy of anti-PD-1/PD-L1 antibody might not be enough to exert a sufficient antitumor effect; additional blockade of immunosuppressive molecules in tumor microenvironment could enhance the antitumor effect of antiPD-1/PD-L1 antibody. Importantly, the production of immunosuppressive molecules in cancer cells is attributed to the activation of cellular signaling through genetic and epigenetic alterations and environmental stimulation, such as inflammation and hypoxia. In this review, we focus on the establishment of immunosuppressive microenvironment of hepatocellular carcinoma in the context of activation of oncogenic signals, and discuss how the immunosuppressive condition could be overcome using tyrosine kinase inhibitors.

๑ 2017 S. Karger AG, Basel
\end{abstract}

(C) 2017 S. Karger AG, Basel

\section{Introduction}

During tumor development, genetic and epigenetic alterations take place that lead to the transformation of hepatocytes [1-5]. These events induce several tumor-associated antigens (TAAs), and a variety of nonsynonymous passenger mutations that could be a source of neoantigen and a target of antitumor immune response.

On the other hand, at the early stage of tumor development, cancer cells are under surveillance of the immune system and could be eliminated by $\mathrm{CD}^{+}$cytotoxic T cells that target TAAs and neoantigens. The extent of TAAspecific $\mathrm{CD}^{+} \mathrm{T}$ cell responses to hepatocellular carcinoma (HCC) is more prominent in patients with an early stage of tumor compared to those in the late stage, and are correlated with survival of the patients [6]. On the contrary, immunosuppressive environment against cancer cells could develop during the progression of tumor, which is attributed to a selective pressure of the immune system on cancer cells. Consequently, less immunogenic tumor cells could survive and expand, which is a phenomenon called immune editing [7] (Fig. 1). During this process, several cytokines, chemokines, growth factors, and metabolites are released from immune cells as well as cancer cells, and contribute to the establishment of an immunosuppressive condition in tumor $[8,9]$. Importantly,

\section{KARGER}

E-Mail karger@karger.com

www.karger.com/ocl
Dr. Naoshi Nishida

Department of Gastroenterology and Hepatology

Kindai University Faculty of Medicine

377-2 Ohno-Higashi, Osaka-Sayama, Osaka 589-8511 (Japan)

E-Mail naoshi@med.kindai.ac.jp 
Fig. 1. Development of immunosuppressive environment in cancer. At the early stage of tumor, cancer cells are under surveillance of natural killer cells (NKs) and cytotoxic T cells (CTLs). During this process, less immunogenic cancer cells are selected (immune editing). Immunosuppressive cytokines, chemokines, growth factors, and metabolites are released from immune cells and cancer cells, and play a role for the development of immunosuppressive microenvironment in tumor at the advanced stage. HCC, hepatocellular carcinoma.

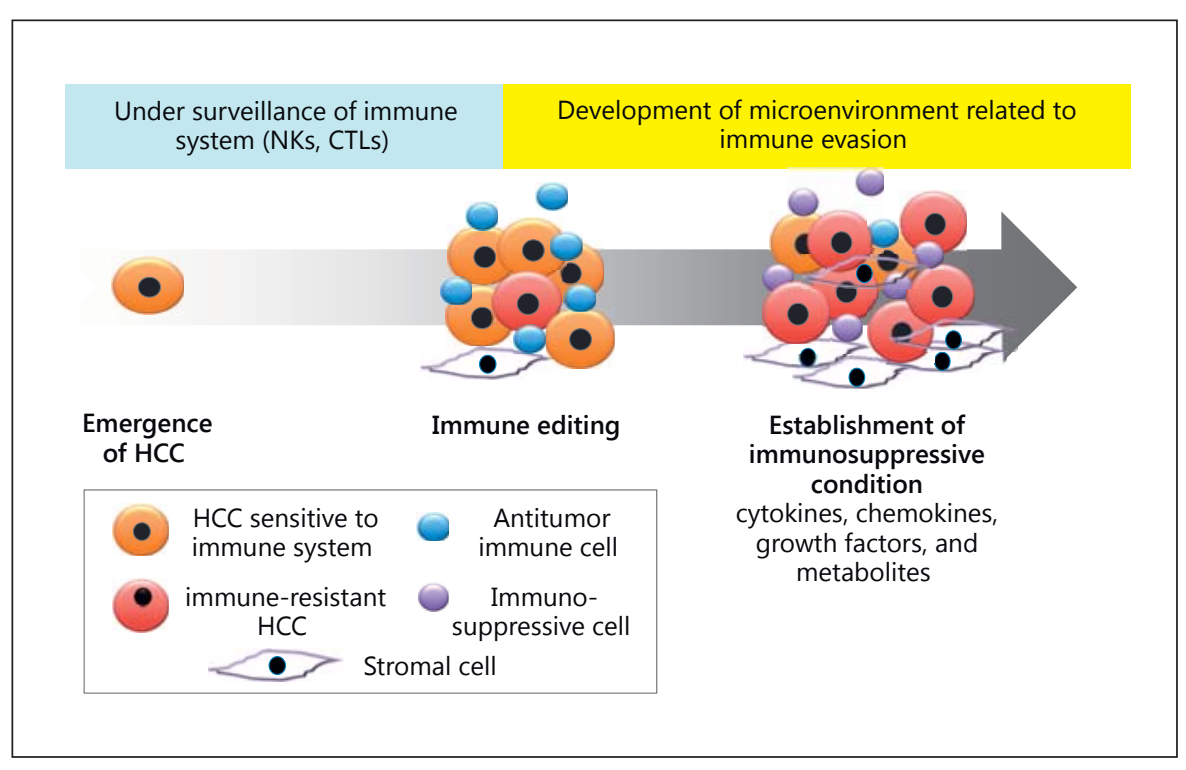

cellular signals activated through genetic and epigenetic alterations could induce the production of immunosuppressive molecules in HCC tissues [8]. In this review, we focus on the establishment of immunosuppressive microenvironment in the context of activation of oncogenic signaling.

\section{Activation of Oncogenic Signaling and Immunosuppressive Molecules}

In melanoma cells, it is reported that constitutive activation of mitogen-activated protein kinase (MAPK) by gain-of-function BRAF mutation $\left(\mathrm{BRAF}^{\mathrm{V} 600}\right)$ induces the increase in interleukin (IL)-6, IL-10, and vascular endothelial growth factor (VEGF), and results in the recruitment of myeloid-derived suppressor cells (MDSCs) and regulatory $\mathrm{T}$ (Treg) cells in tumor tissues [10]. It also reduces the expression of major histocompatibility complex class I molecule, and suppresses the $\mathrm{CD} 8^{+} \mathrm{T}$ cells and natural killer $(\mathrm{NK})$ cells in tumor microenvironment [11-13]. Reportedly, MAPK inhibition increased the number of antigen-specific $\mathrm{CD}^{+} \mathrm{T}$ cells in tumor, and more importantly, combination of MAPK/extracellular signal-regulated kinase (MEK) inhibition with anti-programmed death-ligand 1 (PD-L1) antibody induced a synergistic effect for tumor regression compared to monotherapy of MEK inhibitor or anti-PD-L1 antibody $[13,14]$. These observations indicate that activation of the oncogenic pathway in cancer cells could play an impor-

Oncogenic Signal and Tumor

Microenvironment in HCC tant role for the establishment of immunosuppressive tumor microenvironment.

\section{Induction of Growth Factors}

So far, overexpression of VEGF and basic fibroblast growth factor are reported in HCC tissues compared to noncancerous livers [15]. VEGF is known to induce MDSC accumulation, inhibit maturation of dendritic cells (DCs), and induce Treg cells [16]. VEGF also exerts immunosuppressive function through the expression of immune checkpoint molecules on $\mathrm{CD}^{+} \mathrm{T}$ cells, such as PD-1, T-cell immunoglobulin and mucin domain 3 (TIM-3) and cytotoxic T-lymphocyte antigen-4 (CTLA4) [16]. Expression of VGEF is reportedly controlled by microRNA (miR)-146a as well as hypoxia-inducible factor-1a (HIF-1 $\alpha$ ), and downregulation of miR-146a through DNA methylation takes place in HCC cells [17]. High expression of transforming growth factor- $\beta$ (TGF- $\beta$ ), which is known as an immune modulator, could also be a predictor of poor prognosis in HCC patients [18]; transcriptional expression of TGF- $\beta$ is induced by the activation of $\beta$-catenin, which is one of the commonly mutated genes in HCC [19]. Expression of TGF- $\beta$ leads to the induction of Treg cells, inhibits DCs and NK cell activity [20], and induces expression of TIM-3 on tumorassociated macrophages (TAMs) [21]. Hypoxia in tumor cells also induces HIF-1 $\alpha$ and results in the increase of several immune modulators, such as VEGF, platelet-derived growth factor (PDGF), lactic acid, and adenosine [22].

Oncology 2017;93(suppl 1):160-164 DOI: $10.1159 / 000481246$ 
Fig. 2. Role of activation of oncogenic signal in cancer for development of immunosuppressive microenvironment. Oncogenic signal in hepatocellular carcinoma (HCC) cells, which is activated thorough genetic and epigenetic alterations and environmental factors, could induce the components of tumor microenvironment, such as regulatory $\mathrm{T}$ (Treg), tumor-associated macrophages (TAM), myeloid-derived suppressor cells (MDSC), and cancer-associated fibroblast (CAF).

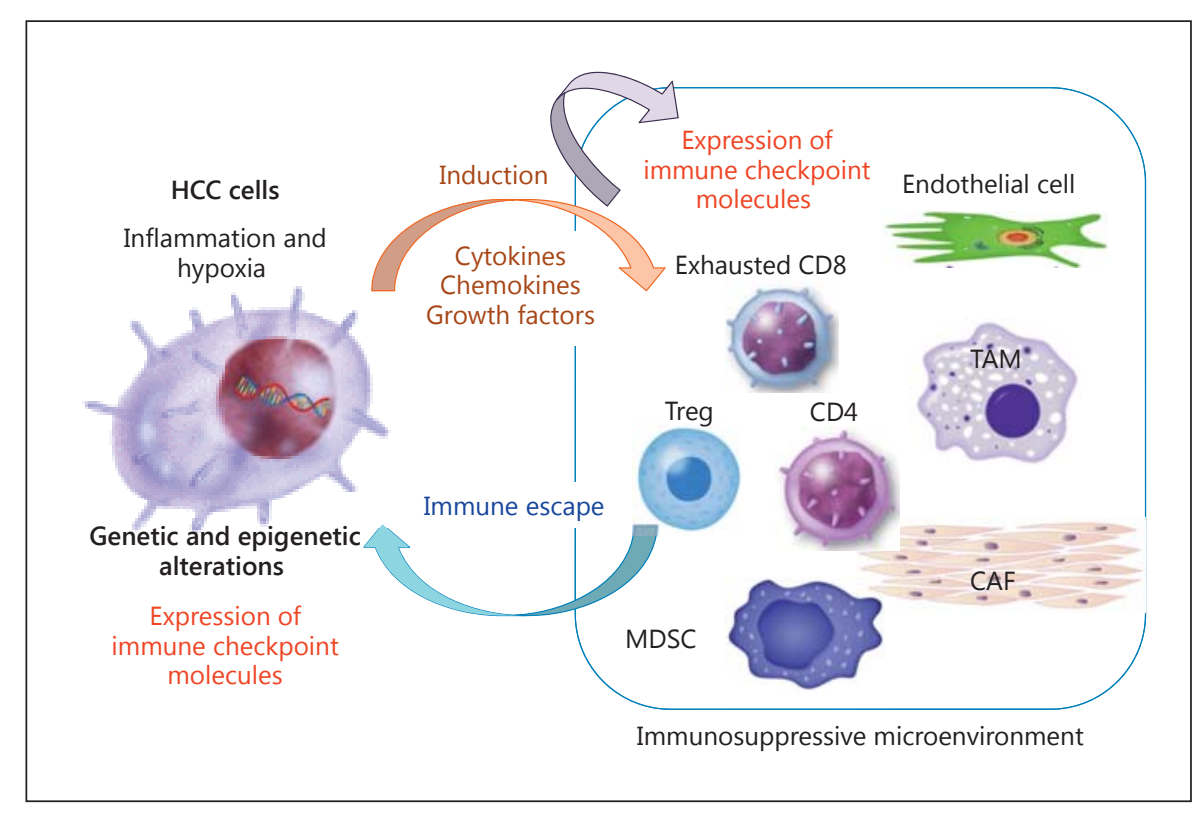

\section{Cytokines, Chemokines, and Metabolites}

HCC cells also produce several cytokines, chemokines, and metabolites as immune modulators to the surrounding environment. Amphiregulin, the ligand of endothelial growth factor receptor (EGFR), could be induced in Treg cells as well as tumor cells [23]. Immunoregulatory enzyme, indoleamine 2,3-dioxygenase (IDO), is overexpressed in HCC cell lines and human HCC tissues, which is an independent prognostic factor for HCC patients [24]. IDO is upregulated by proinflammatory cytokines, such as interferon- $\gamma$, and inhibits T-cell activation and promotes expansion of Treg cells $[25,26]$. Similarly, lactic acid, which is generated through glycolysis in tumor cells, stimulates the expression of VEGF and M2-like polarization of TAMs [27]. Activation of NF- $\kappa B$ could also increase the expression of immunosuppressive cytokines, such as IL-2, IL-6, and IL-8 in cancer cells; intratumoral CC chemokine ligand (CCL)-20 prompts the migration of Treg cells through its receptor CCR6 and plays a role for the establishment of immunosuppressive condition in HCC [28].

\section{Conclusion}

The blockade of PD-1-PD-L1 axis is a promising approach for the control of advanced HCC; the phase I/II trials of nivolumab (CheckMate 040) showed an objective response rate of $20 \%$ and disease control was observed in
64\% of HCC patients [29]. However, several immune modulators are expressed and released from cancer cells through the activation of cellular signaling, which is a consequence of genetic and epigenetic alterations and stimulation of environmental factors such as inflammation and hypoxia (Fig. 2). Therefore, it is conceivable that combination with inhibitors of oncogenic signaling improves the antitumor effect of anti-PD-1 and PD-L1 antibody. For example, IL-6 and PD-L1 blockade combination reportedly inhibits HCC development in mouse model [30]. Inhibition of C-X-C receptor type 4 in tumor microenvironment facilitates anti-PD-L1 immunotherapy of mice HCC [31]. Recently, it was also reported that PD-1 expression promotes tumor growth, where PD-1 binds the downstream effectors of mammalian target of rapamycin (mTOR) and promotes their phosphorylation; the combination of mTOR inhibition with antiPD-1 antibody results in a synergic tumor regression [32]. Based on these findings, clinical trials of immunomodulation of tumor microenvironment through intervention of oncogenic signaling are ongoing [33-39]. These trials include immune checkpoint inhibition combined with tyrosine kinase inhibitors $[40,41]$ and other types of immune checkpoint inhibitors such as CTLA-4 antibody as well as immune checkpoint therapy combined with locoregional therapy such as resection [42$44]$, ablation $[45,46]$, transarterial chemoembolization $[47,48]$, and hepatic arterial infusion chemotherapy [49, 50].
Nishida/Kudo 


\section{Acknowledgements}

This work was supported in part by a Grant-in-Aid for Scientific Research (KAKENHI: 16K09382) from the Japanese Society for the Promotion of Science (N. Nishida) and a grant from the Smoking Research Foundation (N. Nishida).

\section{Disclosure Statement}

The authors have no conflicts of interest to disclose.

\section{Author Contributions}

Naoshi Nishida drafted the manuscript and wrote the final version. Masatoshi Kudo approved the final version of the manuscript.

\section{References}

1 Nishida N: Impact of hepatitis virus and aging on DNA methylation in human hepatocarcinogenesis. Histol Histopathol 2010;25:647654.

2 Nishida N, Kudo M: Recent advancements in comprehensive genetic analyses for human hepatocellular carcinoma. Oncology 2013; 84(suppl 1):93-97.

3 Nishida N, Kudo M: Alteration of epigenetic profile in human hepatocellular carcinoma and its clinical implications. Liver Cancer 2014;3:417-427.

4 Nishida N, Nishimura T, Nakai T, Chishina $\mathrm{H}$, Arizumi T, Takita M, Kitai S, Yada N, Hagiwara S, Inoue T, Minami Y, Ueshima K, Sakurai T, Kudo M: Genome-wide profiling of DNA methylation and tumor progression in human hepatocellular carcinoma. Dig Dis 2014;32:658-663.

5 Nishida N, Kudo M: Clinical significance of epigenetic alterations in human hepatocellular carcinoma and its association with genetic mutations. Dig Dis 2016;34:708-713.

6 Flecken T, Schmidt N, Hild S, Gostick E, Drognitz O, Zeiser R, Schemmer P, Bruns H, Eiermann T, Price DA, Blum HE, NeumannHaefelin C, Thimme R: Immunodominance and functional alterations of tumor-associated antigen-specific CD8+ T-cell responses in hepatocellular carcinoma. Hepatology 2014; 59:1415-1426.

7 Willimsky G, Schmidt K, Loddenkemper C, Gellermann J, Blankenstein T: Virus-induced hepatocellular carcinomas cause antigen-specific local tolerance. J Clin Invest 2013;123: 1032-1043.

8 Nishida N, Kudo M: Immunological microenvironment of hepatocellular carcinoma and its clinical implication. Oncology 2017; 92(suppl 1):40-49.

9 Sia D, Jiao Y, Martinez-Quetglas I, Kuchuk O, Villacorta-Martin C, Castro de Moura M, Putra J, Camprecios G, Bassaganyas L, Akers N, Losic B, Waxman S, Thung SN, Mazzaferro V, Esteller M, Friedman SL, Schwartz M, Villanueva A, Llovet JM: Identification of an immune-specific class of hepatocellular carcinoma, based on molecular features. Gastroenterology 2017;153:812-826.
10 Sumimoto H, Imabayashi F, Iwata T, Kawakami Y: The BRAF-MAPK signaling pathway is essential for cancer-immune evasion in human melanoma cells. J Exp Med 2006;203: 1651-1656.

11 Wilmott JS, Long GV, Howle JR, Haydu LE, Sharma RN, Thompson JF, Kefford RF, Hersey P, Scolyer RA: Selective BRAF inhibitors induce marked T-cell infiltration into human metastatic melanoma. Clin Cancer Res 2012;18:1386-1394.

12 Frederick DT, Piris A, Cogdill AP, Cooper ZA, Lezcano C, Ferrone CR, Mitra D, Boni A, Newton LP, Liu C, Peng W, Sullivan RJ, Lawrence DP, Hodi FS, Overwijk WW, Lizee G, Murphy GF, Hwu P, Flaherty KT, Fisher DE, Wargo JA: BRAF inhibition is associated with enhanced melanoma antigen expression and a more favorable tumor microenvironment in patients with metastatic melanoma. Clin Cancer Res 2013;19:1225-1231.

13 Mandala M, De Logu F, Merelli B, Nassini R, Massi D: Immunomodulating property of MAPK inhibitors: from translational knowledge to clinical implementation. Lab Invest 2017;97:166-175.

14 Ebert PJR, Cheung J, Yang Y, McNamara E, Hong R, Moskalenko M, Gould SE, Maecker $\mathrm{H}$, Irving BA, Kim JM, Belvin M, Mellman I: MAP kinase inhibition promotes $\mathrm{T}$ cell and anti-tumor activity in combination with PDL1 checkpoint blockade. Immunity 2016;44: 609-621.

15 Mise M, Arii S, Higashituji H, Furutani M, Niwano M, Harada T, Ishigami S, Toda Y, Nakayama $\mathrm{H}$, Fukumoto M, Fujita J, Imamura M: Clinical significance of vascular endothelial growth factor and basic fibroblast growth factor gene expression in liver tumor. Hepatology 1996;23:455-464.

16 Voron T, Colussi O, Marcheteau E, Pernot S, Nizard M, Pointet AL, Latreche S, Bergaya S, Benhamouda N, Tanchot C, Stockmann C, Combe P, Berger A, Zinzindohoue F, Yagita H, Tartour E, Taieb J, Terme M: VEGF-A modulates expression of inhibitory checkpoints on CD8+ T cells in tumors. J Exp Med 2015;212:139-148.
17 Zhang Z, Zhang Y, Sun XX, Ma X, Chen ZN: microRNA-146a inhibits cancer metastasis by downregulating VEGF through dual pathways in hepatocellular carcinoma. Mol Cancer 2015; 14:5.

18 Peng L, Yuan XQ, Zhang CY, Ye F, Zhou HF, Li WL, Liu ZY, Zhang YQ, Pan X, Li GC: High TGF-betal expression predicts poor disease prognosis in hepatocellular carcinoma patients. Oncotarget 2017;8:34387-34397.

19 Wu J, Lu M, Li Y, Shang YK, Wang SJ, Meng Y, Wang Z, Li ZS, Chen H, Chen ZN, Bian H: Regulation of a TGF-beta1-CD147 self-sustaining network in the differentiation plasticity of hepatocellular carcinoma cells. Oncogene 2016;35:5468-5479.

20 Sprinzl MF, Reisinger F, Puschnik A, Ringelhan M, Ackermann K, Hartmann D, Schiemann M, Weinmann A, Galle PR, Schuchmann M, Friess H, Otto G, Heikenwalder M, Protzer U: Sorafenib perpetuates cellular anticancer effector functions by modulating the crosstalk between macrophages and natural killer cells. Hepatology 2013;57:2358-2368.

21 Yan W, Liu X, Ma H, Zhang H, Song X, Gao L, Liang X, Ma C: Tim-3 fosters HCC development by enhancing TGF-beta-mediated alternative activation of macrophages. Gut 2015;64:1593-1604.

22 Prieto J, Melero I, Sangro B: Immunological landscape and immunotherapy of hepatocellular carcinoma. Nat Rev Gastroenterol Hepatol 2015;12:681-700.

23 Castillo J, Goni S, Latasa MU, Perugorria MJ, Calvo A, Muntane J, Bioulac-Sage P, Balabaud C, Prieto J, Avila MA, Berasain C: Amphiregulin induces the alternative splicing of p73 into its oncogenic isoform DeltaEx2p73 in human hepatocellular tumors. Gastroenterology 2009;137:1805-1815.e1-4.

24 Pan K, Wang H, Chen MS, Zhang HK, Weng DS, Zhou J, Huang W, Li JJ, Song HF, Xia JC: Expression and prognosis role of indoleamine 2,3-dioxygenase in hepatocellular carcinoma. J Cancer Res Clin Oncol 2008;134:1247-1253.

25 Belladonna ML, Orabona C, Grohmann U, Puccetti P: TGF-beta and kynurenines as the key to infectious tolerance. Trends Mol Med 2009; 15:41-49.
Oncogenic Signal and Tumor

Microenvironment in HCC
Oncology 2017;93(suppl 1):160-164 DOI: $10.1159 / 000481246$ 
26 Mezrich JD, Fechner JH, Zhang X, Johnson BP, Burlingham WJ, Bradfield CA: An interaction between kynurenine and the aryl hydrocarbon receptor can generate regulatory $\mathrm{T}$ cells. J Immunol 2010;185:3190-3198.

27 Colegio OR, Chu NQ, Szabo AL, Chu T, Rhebergen AM, Jairam V, Cyrus N, Brokowski CE, Eisenbarth SC, Phillips GM, Cline GW, Phillips AJ, Medzhitov R: Functional polarization of tumour-associated macrophages by tumour-derived lactic acid. Nature 2014;513: 559-563.

28 Chen KJ, Lin SZ, Zhou L, Xie HY, Zhou WH, Taki-Eldin A, Zheng SS: Selective recruitment of regulatory T cell through CCR6-CCL20 in hepatocellular carcinoma fosters tumor progression and predicts poor prognosis. PLoS One 2011;6:e24671.

29 El-Khoueiry AB, Sangro B, Yau T, Crocenzi TS, Kudo M, Hsu C, Kim TY, Choo SP, Trojan J, Welling THR, Meyer T, Kang YK, Yeo W, Chopra A, Anderson J, Dela Cruz C, Lang L, Neely J, Tang H, Dastani HB, Melero I: Nivolumab in patients with advanced hepatocellular carcinoma (CheckMate 040): an open-label, non-comparative, phase 1/2 dose escalation and expansion trial. Lancet 2017; 389:2492-2502.

30 Liu H, Shen J, Lu K: IL-6 and PD-L1 blockade combination inhibits hepatocellular carcinoma cancer development in mouse model. Biochem Biophys Res Commun 2017;486:239244.

31 Chen Y, Ramjiawan RR, Reiberger T, Ng MR, Hato T, Huang Y, Ochiai H, Kitahara S, Unan EC, Reddy TP, Fan C, Huang P, Bardeesy N, Zhu AX, Jain RK, Duda DG: CXCR4 inhibition in tumor microenvironment facilitates anti-programmed death receptor-1 immunotherapy in sorafenib-treated hepatocellular carcinoma in mice. Hepatology 2015;61: 1591-1602.
32 Li H, Li X, Liu S, Guo L, Zhang B, Zhang J, Ye $\mathrm{Q}: \mathrm{PD}-1$ checkpoint blockade in combination with an mTOR inhibitor restrains hepatocellular carcinoma growth induced by hepatoma cell-intrinsic PD-1. Hepatology 2017, DOI: 10.1002/hep.29360

33 Kudo M: Immune checkpoint blockade in hepatocellular carcinoma: 2017 update. Liver Cancer 2016;6:1-12.

34 Kudo M: Recent trends in the management of hepatocellular carcinoma with special emphasis on treatment with regorafenib and immune checkpoint inhibitors. Dig Dis 2016;34: 714-730.

35 Nishida N, Kitano M, Sakurai T, Kudo M: Molecular mechanism and prediction of sorafenib chemoresistance in human hepatocellular carcinoma. Dig Dis 2015;33:771-779.

36 Smyth MJ, Ngiow SF, Ribas A, Teng MW: Combination cancer immunotherapies tailored to the tumour microenvironment. Nat Rev Clin Oncol 2016;13:143-158.

37 Kudo M: Immune checkpoint inhibition in hepatocellular carcinoma: basics and ongoing clinical trials. Oncology 2017;92(suppl 1):5062.

38 Kudo M: Molecular targeted agents for hepatocellular carcinoma: current status and future perspectives. Liver Cancer 2017;6:101112.

39 Kudo M: Immune checkpoint blockade in hepatocellular carcinoma. Liver Cancer 2015;4: 201-207.

40 Kudo M: Regorafenib as second-line systemic therapy may change the treatment strategy and management paradigm for hepatocellular carcinoma. Liver Cancer 2016;5:235-244.

41 Kudo M: Molecular targeted therapy for hepatocellular carcinoma: where are we now? Liver Cancer 2015;4:I-vii.
42 Kudo M, Izumi N, Sakamoto M, Matsuyama Y, Ichida T, Nakashima O, Matsui O, Ku Y, Kokudo N, Makuuchi M: Survival analysis over 28 years of 173,378 patients with hepatocellular carcinoma in Japan. Liver Cancer 2016;5:190-197.

43 Ho MC, Hasegawa K, Chen XP, Nagano H, Lee YJ, Chau GY, Zhou J, Wang CC, Choi YR, Poon RT, Kokudo N: Surgery for intermediate and advanced hepatocellular carcinoma: a consensus report from the 5th Asia-Pacific Primary Liver Cancer Expert Meeting (APPLE 2014). Liver Cancer 2016;5:245-256.

44 Kudo M: Surveillance, diagnosis, treatment, and outcome of liver cancer in Japan. Liver Cancer 2015;4:39-50.

45 Kang TW: Recent advances in tumor ablation for hepatocellular carcinoma. Liver Cancer 2015;4:176-187.

46 Lencioni R, de Baere T, Martin RC, Nutting CW, Narayanan G: Image-guided ablation of malignant liver tumors: recommendations for clinical validation of novel thermal and non-thermal technologies - a Western perspective. Liver Cancer 2015;4:208-214.

47 Kudo M: Locoregional therapy for hepatocellular carcinoma. Liver Cancer 2015;4:163164.

48 Tsurusaki M, Murakami T: Surgical and locoregional therapy of HCC: TACE. Liver Cancer 2015;4:165-175.

49 Obi S, Sato S, Kawai T: Current status of hepatic arterial infusion chemotherapy. Liver Cancer 2015;4:188-199.

50 Lin CC, Hung CF, Chen WT, Lin SM: Hepatic arterial infusion chemotherapy for advanced hepatocellular carcinoma with portal vein thrombosis: impact of early response to 4 weeks of treatment. Liver Cancer 2015;4: 228-240. 